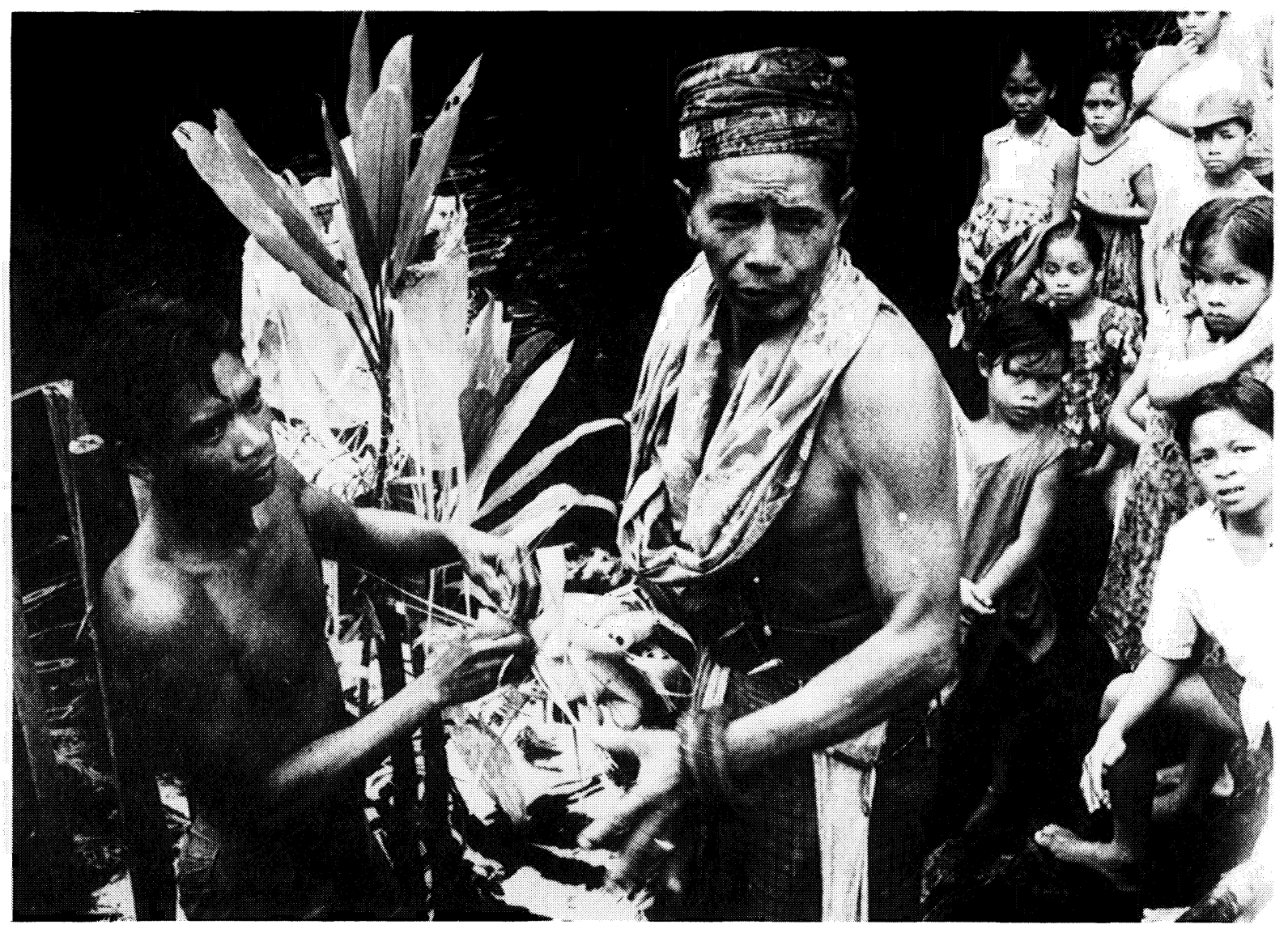

Bawu shaman participating in a spirit propitiation ritual 


\title{
SOME OBSERVATIONS ON DANCE IN KALIMANTAN
}

\author{
Judith M. Hudson
}

The Padju Epat Ma'anjan of Central Kalimantan will already be familiar to readers of the first four issues of Indonesia. ${ }^{\text {Although }}$ its population was positively oriented to the modern world of 1964 , Padju Epat's rather isolated location forced its inhabitants to depend on their own resources in most spheres of life. Given the dispersed field settlement pattern associated with the area's dominant swidden subsistence system and the relative seclusion of its villages, the average inhabitant led a quiet existence, having frequent contact with only the other members of his immediate family and, perhaps, those of the one or two families that worked farms near his own. In the face of this prevalent and often dispiriting isolation, any large gathering of people took on a festive air. Whatever the ostensible purpose for the gathering, whether to celebrate the birth of a child or to effect the cure of an ailing villager, such affairs generally fulfilled the important secondary function of providing entertainment for both participants and onlookers. With the exception of rituals associated with death, one of the most pervasive elements associated with public gatherings of al1 kinds, and one which ranked high on the villagers' entertainment scale, was dance. Ma'anjan of all ages and religious persuasions delighted in dance performances, lining the village street to watch a modern "evening with the arts," crowding into a hot, stuffy room to see a shaman in action, or joining in the frenzied celebration that marked the conclusion of the death ceremonial cycle.

Because of the important place that dance has played in the traditional life of Padju Epat, and because there has been little published on dance in this area, it seems appropriate to present this brief description of $\mathrm{Ma}^{\prime}$ anjan dance in a publication dedicated to the memory of Claire Holt. Although I have received no formal training either as a dancer or as a dance investigator, I did have the privilege to serve as Mrs. Holt's research assistant, during which time I absorbed some general knowledge related to dance in Indonesia. In addition, at the time I lived in Padju Epat, I witnessed and participated personally in enough dancing to compile the following description. It is a document which, while not technically sophisticated, may be of some interest to researchers in the Indonesian dance field.

This description pertains specifically to dance in Padju Epat in 1964 , but in its general features is probably applicable to other

1. See J. Hudson, "Letters from Kalimantan: I-III," in Indonesia, Nos. 1-3 (April 1966, October 1966, April 1967), and A. Hudsón, "The Padju Epat Ma'anjan Dajak in Historical Perspective," Indonesia, No. 4 (October 1967). For maps of the area, see those reproduced in "Letters," No. 1, p. 81 and "The Padju Epat Ma'anjan," pp. 32 and 36 . 
Ma'anjan subgroups. ${ }^{2}$ Temporally, dance in Padju Epat has probably changed somewhat since 1964 , particularly as regards the relative balance between what must be distinguished as the "traditional" and "modern" sectors of the dance world.

For dance, like most other things in Padju Epat, despite its relatively isolated location, is undergoing change stimulated by the introduction of new elements from the outside. I term these elements "modern" both because they are new in the Padju Epat region, and because most of them are associated in the villagers' minds with a new pan-Indonesian or pan-provincial life-style that is perceived as progressive or moderen. Modern influences have affected the form, style, and context of Padju Epat dance in various ways, including the introduction of new dance forms, the establishment of new contexts for the performance of traditional dances, and the injection of new performance styles into traditional dance forms. In order to simplify the process of description, I will treat first the formal, stylistic, and contextual elements of the traditional sector before moving on to a consideration of the modern sector.

Before continuing, a word of clarification concerning the accompanying photographs is necessary. With the exception of the dibble stick dance, both traditional and modern dance is normally performed at night, rendering photography difficult. Indoor performances, especially, took place under such crowded conditions that photography was impossible. Most of the illustrative photographs used herein were taken at a specially convened daylight session organized by our friends in the village of Murutuwu for the sole purpose of recording dance segments on film, and thus are not illustrative of normal performance conditions.

In traditional Padju Epat society, dance occurs in ritual or ceremonial contexts. Dance, moreover, is a celebration of life: Ma'anjan adat proscribes any dancing during the elaborate ceremonial cycle that accompanies death. The end of the death ritual, a symbolic "return to life," is marked by a frenzied, often tranceinducing dance performance. Dance also carries the healer-shaman on his journey to the spirit world; in states of trance induced by repetitious dance movements, the shaman can effect a cure by enticing a wayward spirit back to the body of its owner. Traditional$1 y$, dance also appeared in one, very restricted context, limited to occasions of cooperative rice planting, where it served only as entertainment and had no ritual associations.

Dance is not restricted to specialists and may be performed by either men or women. Participation in public dancing begins about the age of adolescence. Smaller children may imitate their elders surreptitiously on the sidelines, but they are rarely pushed out to perform in public. The most skilled dancers were the old people,

2. See A. Hudson, "The Padju Epat Ma'anjan," pp. 29-32, and J. Hudson, "Letters," No. 3, p. 93. The major element that distinguishes these groups from Padju Epat is their differential treatment of the dead, and death ritual is the one significant realm in the Padju Epat 1ife-sphere from which local adat specifically proscribes any form of dance. 
whose graceful movements betrayed none of the self-consciousness of the youths. A boy or girl was not specially trained as a dancer, but learned from participating on ceremonial occasions, when everyone was encouraged, cajoled, or sometimes forced to take part in dances. An apprentice shaman, however, would study dance along with the other magical arts of her trade. Some young people exhibited considerable natural aptitude as dáncers, and no doubt these individuals will emerge one day as a new generation of expert dancers.

Certain features characterize Ma'anjan dance style in general. The dancer typically moves with bent knees, and may lower his body even closer to the ground as his steps become more exuberant. His steps are measured, often springy, as he slams his heel on the floor then rolls his foot forward to rise on his toes. Ostinato rhythms are of great importance in the dance, and often the dancer himself establishes a persistent, repetitious beat that may be syncopated in relation to the basic rhythms of the dance accompaniment. Often a rhythmic competition arises between dancer and orchestra, providing great amusement to the spectators. Dance accessories include scarves or selendang, and bronze bracelets or rattles with sticks that the dancers use in establishing ostinato-type rhythms. Special costumes

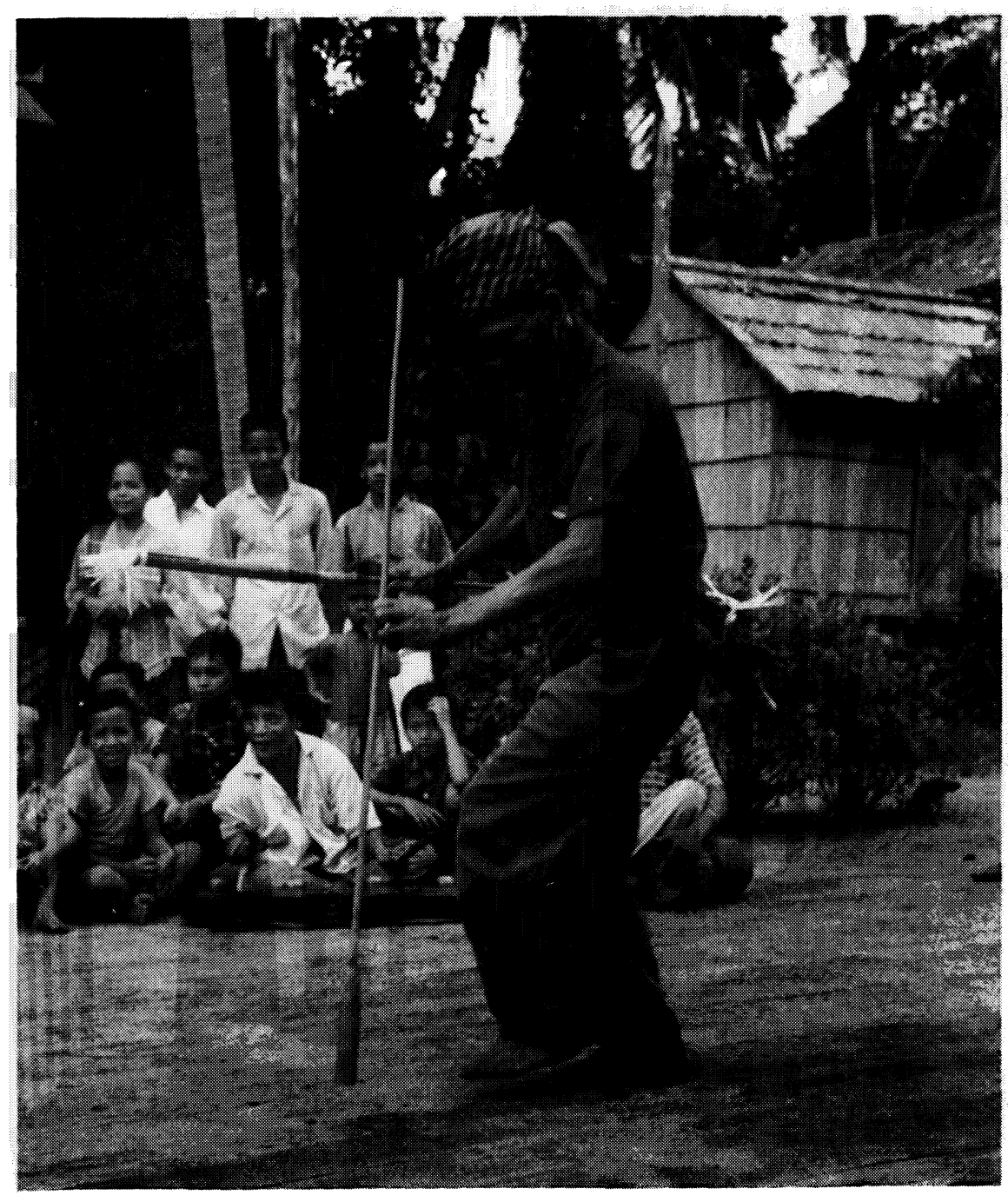

Seser bunser, an old man's style of giring-giring 
that have magical attributes are worn by shamans. Other dancers wear either everyday attire or their best party or ceremonial clothes, depending upon the occasion. Men traditionally wear wrapped headcloths at any kind of festive affair.

Dance is generally accompanied by drums and gongs. The principal instruments are a set of five small bronze gongs, hit with rubber-tipped drumsticks and a single-headed drum struck with the fingers. In shaman ceremonies, larger gongs or hoop drums are added.

Three basic dance forms are traditional among the Ma'anjan: (1) dances with rattles and staffs; (2) dances with scarves or selendang; and (3) dances with bracelets, this latter being limited exclusively to shamans.

The first of these dance forms is known as giring-giring or gangiring by the Ma'anjan. The most popular of all Ma'anjan dances, giring-giring is the principal dance of the three-day ritual (shiwa) performed seven days after the completion of the idjambe cremation ceremony. The shiwa rite celebrates the community's final separation from the spirits of the deceased, the purification of the village from the frightening powers of death, and the return to the life, as opposed to the death, way or adat. In olden days, giring-giring was said to occur at the rites accompanying the reception into the village of a newly taken head.

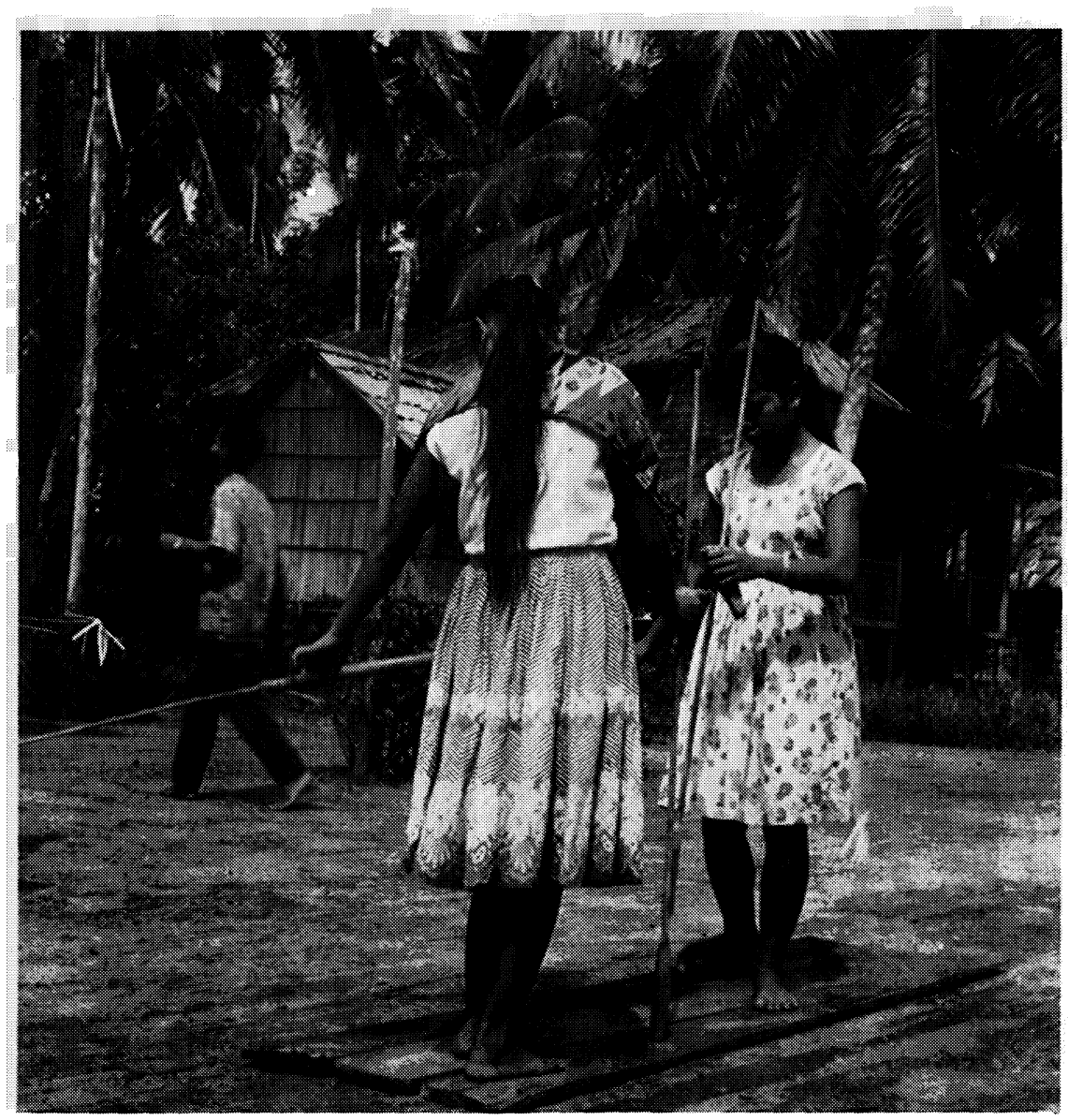

Women's giring-giring style 


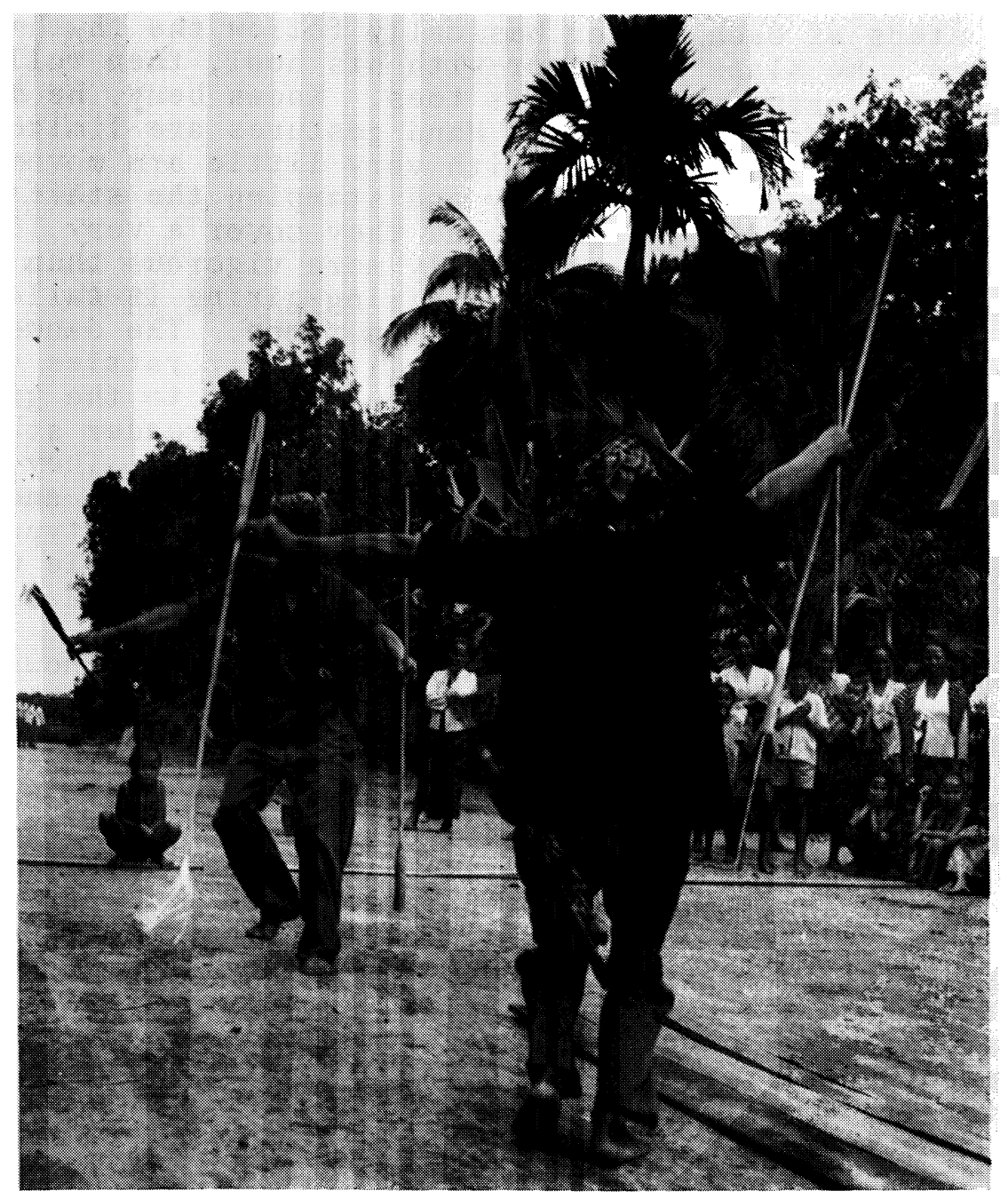

Men's giring-giring style

The dance is normally performed by two individuals, usually two men or two women, although occasionally a youth and a girl will dance together. Traditionally it was a man's dance, in which the performers engaged in a mock combat. Each dancer holds a staff upright in his right hand, and in his left, balances a long stick with an attached rattle. The rattle was said to represent a spear; the staff was once attached to a shield. With these weapons, the dancer strikes up a fixed beat by shaking the rattle; he pounds the staff in complex syncopations on the resonant board floor. The main characteristic of the dance is a rhythmic contest between the two performers; each attempts to confuse the other by setting up a fixed rhythmic pattern, then getting his opponent to misstep by pounding his staff at the wrong instant. Initially the dancer adopts the rhythmic pattern of the gamelan accompaniment, but then, as the competition grows more intense, the dancer's rhythms take on an independent life of their own as he improvises dance steps of increasing complexity. Once the dance may have been a stylized combat between two warriors, each brandishing his weapon, but now the mock battle is fought entirely on rhythmic grounds. 
The steps of each dancer basically follow the rhythm that he establishes. He slaps the floor with his heel, then rolls his foot forward, springing up on his toes. Knees bent, he may cross one foot in front of the other. Hand gestures are limited by the staff and rattle. Women dance with very little arm movement, merely shaking the rattle lightly and stamping the staff; their steps are correspondingly small, and they cover a very limited area. Men's gestures are characteristically more vigorous than those of the women. One special variety of giring-giring is called seser bunser; its distinctive tune is slow in tempo. The dancers employ broad, expansive arm gestures. They lift their rattles and staffs to the full extent of their reach, crouch lower to the ground, and raise their feet higher off the ground. With broader steps, they traverse wide spaces, using slow, bobbing motions. They balance on one leg, lower their bodies by bending their knees and step across onto the other leg. Reportedly the principal type of giring-giring used in the shiwa celebration, this style was appropriate only for men, and was usually danced by the older men.

The dance with a selendang, or dance shawl, is known as tanrik bahalai, a purely descriptive name meaning "dance (with) selendang." Like giring-giring, the selendang dance is performed in the ritual context of the shiwa celebration, where it comes as the dramatic climax of the abrupt transition between death and 1 ife customs. As we have described in more detail elsewhere, ${ }^{3}$ offerings are carried to the wooded cremation site, in a final tribute to the spirits of the dead, and then preparations are made for a mock combat. Some men and youths remain at the cremation ground to become a party of invaders, while most of the villagers hurriedly return to defend the ceremonial hall. The light tinkling of the dance gamelan can be heard in the ceremonial hall, as someone tries a few experimental rhythms. Then the attacking party swoops out of the forest; a swirling, frenzied confrontation with the defenders ensues. The raiders, their leader holding aloft a shield and ancient skull fragment, relic of bygone headhunting days, storm up the notched pole into the ceremonial hall. The gamelan strikes up the insistent, repetitious traditional tune of seser bunser. The raiders drape heirloom red cloths (tjindai) over their shoulders, and begin the lilting steps of the selendang dance, dancing with an intensity that is more notable because the dance movements themselves are so tightly controlled. The measured concentration of the dancers, the suggestive repetitious rhythms, and the emotionally charged atmosphere can quickly lead to trance:

Within three to five minutes, a dancer was "in"; his body stiffened up, he began to jump up and down in very tight frenzied movements. Someone pushed him over, and he toppled like a lead solder. He lay down for a while, was helped up again, but was still "in." Some experienced men took him to a corner and brought him out of the trance.

3. A. Hudson, "Death Ceremonies of the Padju Epat Ma'anjan Dayaks," in Tom Harrisson (ed.), Borneo Writing (Kuching: The Museum, 1966), pp. 399-401, and' J. Hudson, "Letters," No. 2, pp. 3435 . 
The total scene within the ceremonial hall is nearly chaotic: spectators crowd the outside porches, eight or ten men and women dance, while young women rush around the dancers painting their cheeks with tar and pouring coconut oil on their heads. In the midst of this, a man (or sometimes a woman) grabs a smoldering incense pot and a frond of leaves. He clowns about, dancing with exaggerated gestures, sweeping around under the feet of the intense dancers. ${ }^{4}$

Before beginning to dance, the performer passes a selendang over his shoulders; the ends of the cloth hang nearly to the ground. He picks up an edge of the cloth in each hand, then spreads his arms to give the appearance of a giant bird. As he dances, he moves his arms as if they were joined together, incapable of independent movement. One hand follows the lead of the other, and the cloth creates rippling wings. The dancer's knees are bent; he raises and lowers his body on pliant knees as he moves his feet in a measured, springy step. His heel hits the floor first; then he shifts his weight onto his toes. Although an experienced dancer may lift his feet off the ground and slap the floor rhythmically with his bare feet as he steps, there is no sense of hopping, no abrupt movement. The tempo of the dance remains slow, the short, rhythmical tune being repeated throughout. The impression of the whole figure is of great fluidity, of continuous movement as the dance progresses. The dancer inclines his head slightly toward the ground; he raises one hand in front of his face, while the hand in back drops; the giant bird is wheeling and soaring in the sky. While any number of dancers perform at the same time, each moves individually, and there is no coordination of the group as a whole.

As part of the life ritual, the selendang dance is symbolic of man's release from the fears of death and from his personal grief; it is indeed both an emotional and an artistic climax. A skilled dancer, either man or woman, can create an absorbing spectacle. This was a dance at which the elderly were particularly outstanding, while the inexperienced seemed to find it a prolonged embarrassment, their dancing being self-conscious and uncoordinated.

A shaman's curing ceremony is a high point in the life of a Padju Epater. As dusk falls, the gongs are sounded, heralding the ritual about to begin. The villagers hear the familiar rhythms and accept their open invitation to an evening's entertainment.

Both men and women may become shamans among the Ma'anjan. However, of the five types of healer-shaman, four are restricted to women practitioners, and one to men. ${ }^{5}$ Each type of shaman has distinctive attributes: costume, ritual chants, dance tunes, dance forms and, of course, particular spirits from whom their powers

4. This last dancer provided great amusement to the audience, but no one could tell me more about his significance than that he was just "clowning around."

5. Women healer-shamans (wadian) are known as amunrahu, tapu' onrou, dapa' and dadas. The male healer-shaman is called bawu. The Ma'anjan also have two other wadian, or shamans, the maianjan and the pisambe, the latter associated exclusively with death ritual. The former is a priestess who chants at both life and death rites. Neither of these two shamans ever danced. 
derive. Roughly equivalent in function, individual shamans are recognized for particularistic skills, such as their dancing or singing prowess or their more potent abilities as curers.

A healing ceremony involves considerable preparation by the shaman, who must arrange both ritual offerings and her personal dance paraphernalia before the actual performance may begin. Around a central pole inside the house, batik or other cloths are hung from the rafters. Decorations fashioned from palm fronds and flowers are fastened to the pole, and other vesse1s, plates, and trays are piled about. Eggs, rice, and offerings are heaped together with the other equipment. Prospective patients sit or 1 ie near this ritual array. Two or more medium-sized gongs are hung near the door, and men begin to strike the familiar rhythmic motifs associated with each type of shaman. A set of five small gongs and drum may be added to the gamelan orchestra; hoop drums hit with rattan sticks provide a distinctive accompaniment to the male shaman's performance. The booming of the gongs, meant to call the spirits to a ceremony that is beginning, also serves to attract the villagers who throng into the house and sit on the floor.

The ritual is rarely conducted by a single practitioner; most often, several skilled specialists perform together, or a senior shaman will be assisted by her pupils. In performance, the shaman requires help with costuming and manipulation of her equipment. If a trance performance is anticipated, another skilled specialist will always be present to help control the entranced performer, for frightening, malevolent spirits may appear during possession.

Special clothing is donned as a prelude to performance. Women wear a batik sarong, tied above the breasts, a linked silver belt, and tie other scarves tightly about their hips, the ends flowing loose. For some types of shaman, these serve as dance scarves. Another important dance accessory is a set of bronze bracelets which are rhythmically shaken as the shaman dances. Magical decorations are painted on arms, throat, or chest with lime or other substances. Women tie bands around their foreheads, but uncoil their long black hair so it falls loosely down to their waists. Male shamans wear a sarong about their waists, and a specially decorated hanging sash. They don crossed strings of animal teeth and shells over their bare torsos and wind a turban about their heads. Finally they put a pair of heavy bronze bracelets on each wrist that are also used as rhythmical accessories.

A curing ceremony is inevitably slow in beginning. The hot room becomes increasingly $j$ ammed with spectators, who gossip or nap despite the din of the gongs. The shamans busy themselves in getting into their costumes; last of all they squeeze their hands into their dance bracelets. The dancing begins gradually, as each shaman makes a few experimental shakes of her bracelets, testing their sound. She begins to dance, establishing a strong rhythm with her bracelets, but at first tries only three or four steps in succession. The orchestra attempts to confuse the dancer with syncopated rhythms, and she engages in sharp repartee with the musicians, exclaiming that their playing is faulty. Finally, calling on her spirits, she goes to the open door, where she begins a few slow dance steps. She dances back into the room, circling the central offering pile, then back out again. Into the room and out again she dances, as the rhythms grow more and more insistent. Her bracelets jangle in a repetitious, hypnotic beat. Her steps become 


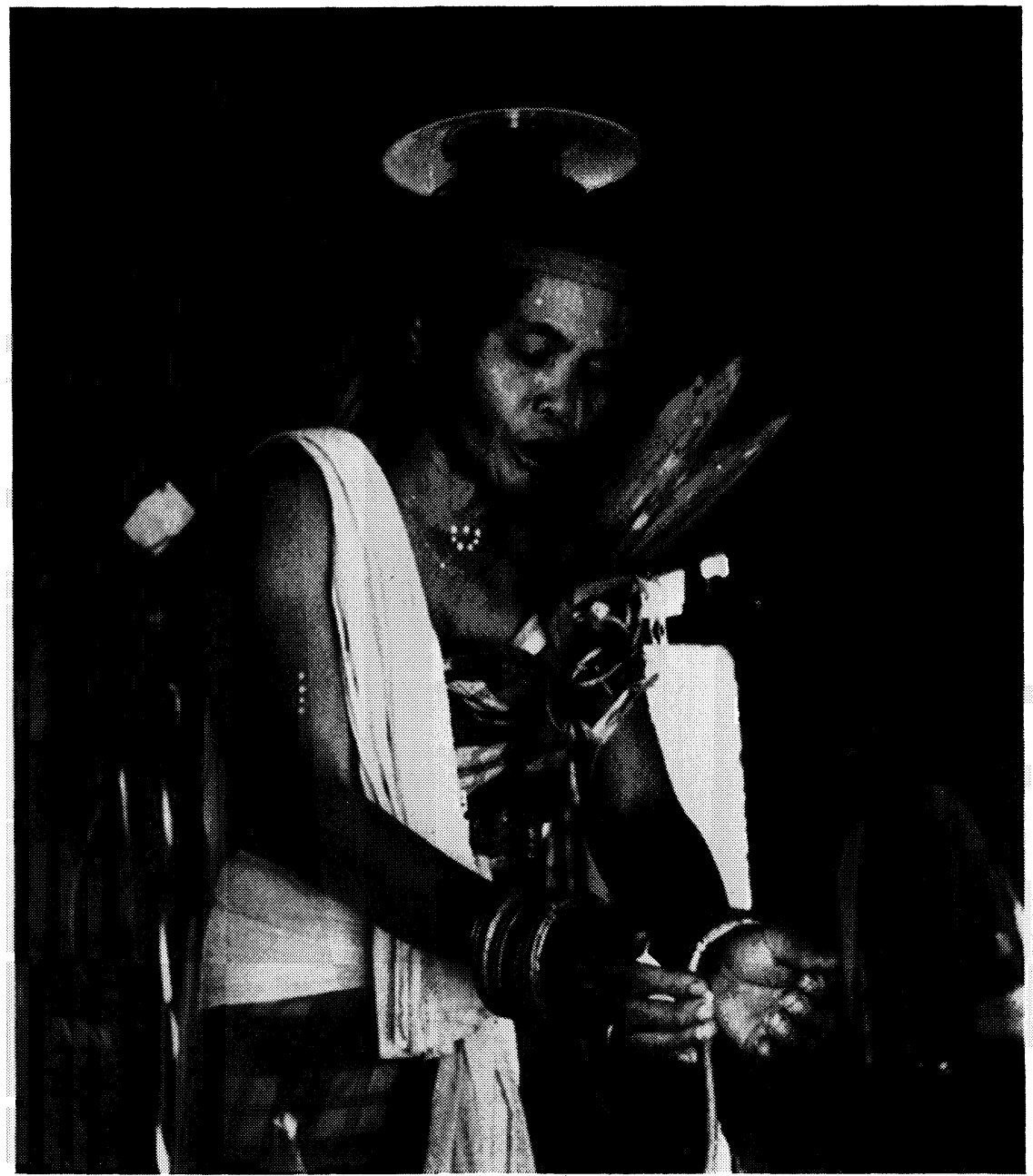

Tapu' onrou shaman singing during a curing ceremony

faster, her gestures more intense. Her hair flies wildly about, the restraining headband having disappeared; her audience watches breathlessly. Abruptly, she sits down, and is handed an unfortunate sacrificial chicken with which she begins to gesticulate. Entranced, she has entered into direct communication with the spirit world, and people shout at her, showering her with questions or ribald remarks.

Fast, repetitive dance is not the door to trance for all shamans; some become possessed by clutching a hanging cloth and swaying rhythmically, only beginning actual dance steps once fully entranced. For the male shaman, dance is only part of his performance and has no direct relation with trance. Yet in all curing ceremonies, dance is a necessary part of the ritual.

There are three forms of shaman dance: female shamans using dance scarves; female shamans dancing with bracelets; and male shamans dancing with heavy bronze bracelets. Of the four types of female healer-shaman, informants said that one, known as amunrahu, who dances with a dance scarf, was the original Ma'anjan curer. A second type, dadas, dances primarily with bracelets; this shaman type was said to have developed within the past ten generations. The other two shaman types, tapu' onrou and dapa', employ both forms of dance. 
142

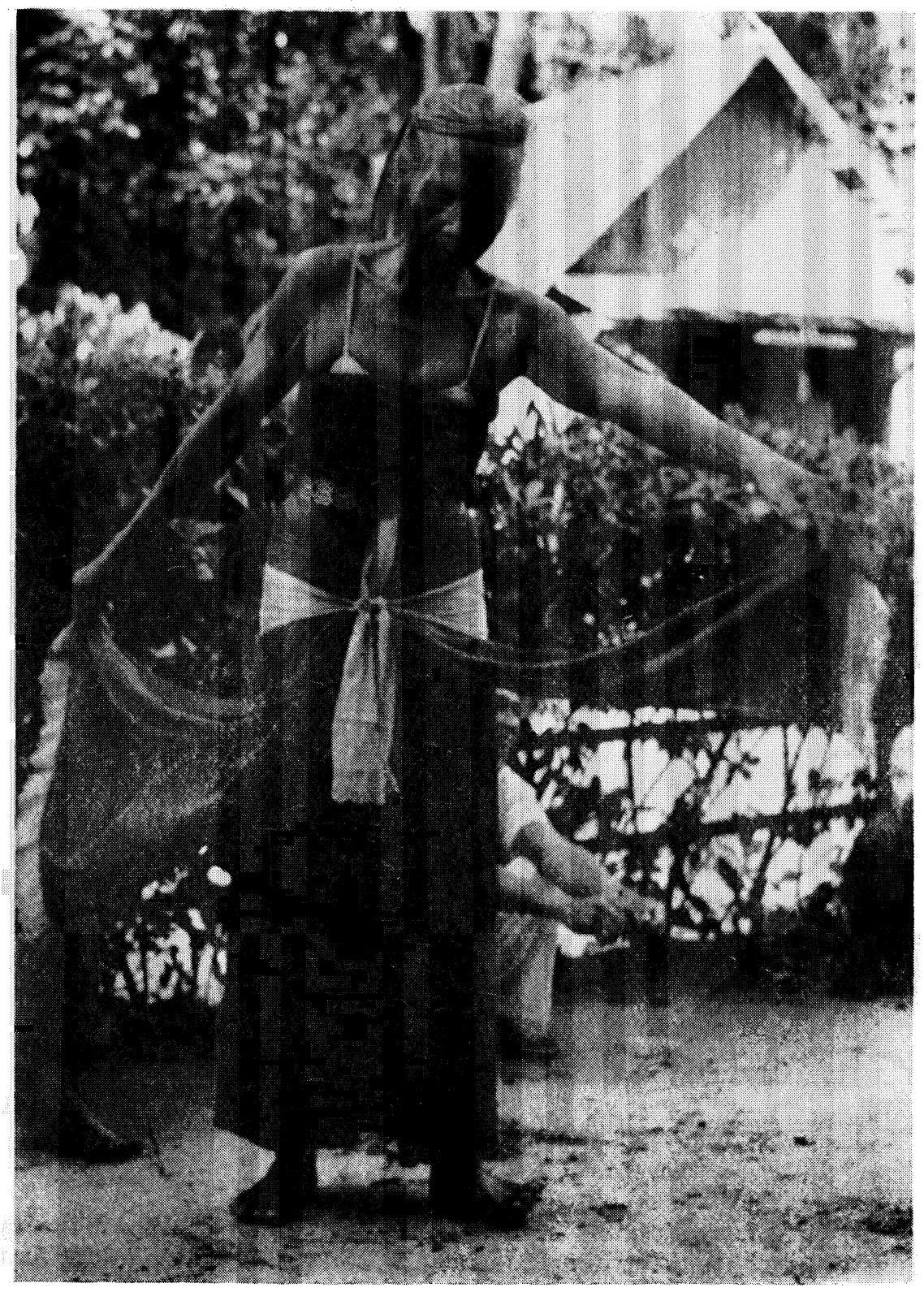

Amunrahu shaman illustrating the dance with a scarf

However, neither use the bracelet dance to enter trance, and one might infer from this that these types are derivative of the amunrahu tradition, the occasional insertions of bracelet dancing being an influence from the more spectacular dadas.

The dance scarf is used by the shaman in much the same way as another Ma'anjan dancer uses a selendang. The scarf, however, is passed about the dancer's waist, pulled tight around her hips and across her buttocks, and tied in front. Thus she must pick up the dangling ends from her waist, almost in the manner of a Javanese dancer. Although the folds of the cloth do not create the winged effect of the selendang dance, the dancer's movements are nearly identical to those of the selendang dancer. The most skilled scarf dancing of this type occurs when the shamans are in trance, although there is considerable difference between the trance performances of 


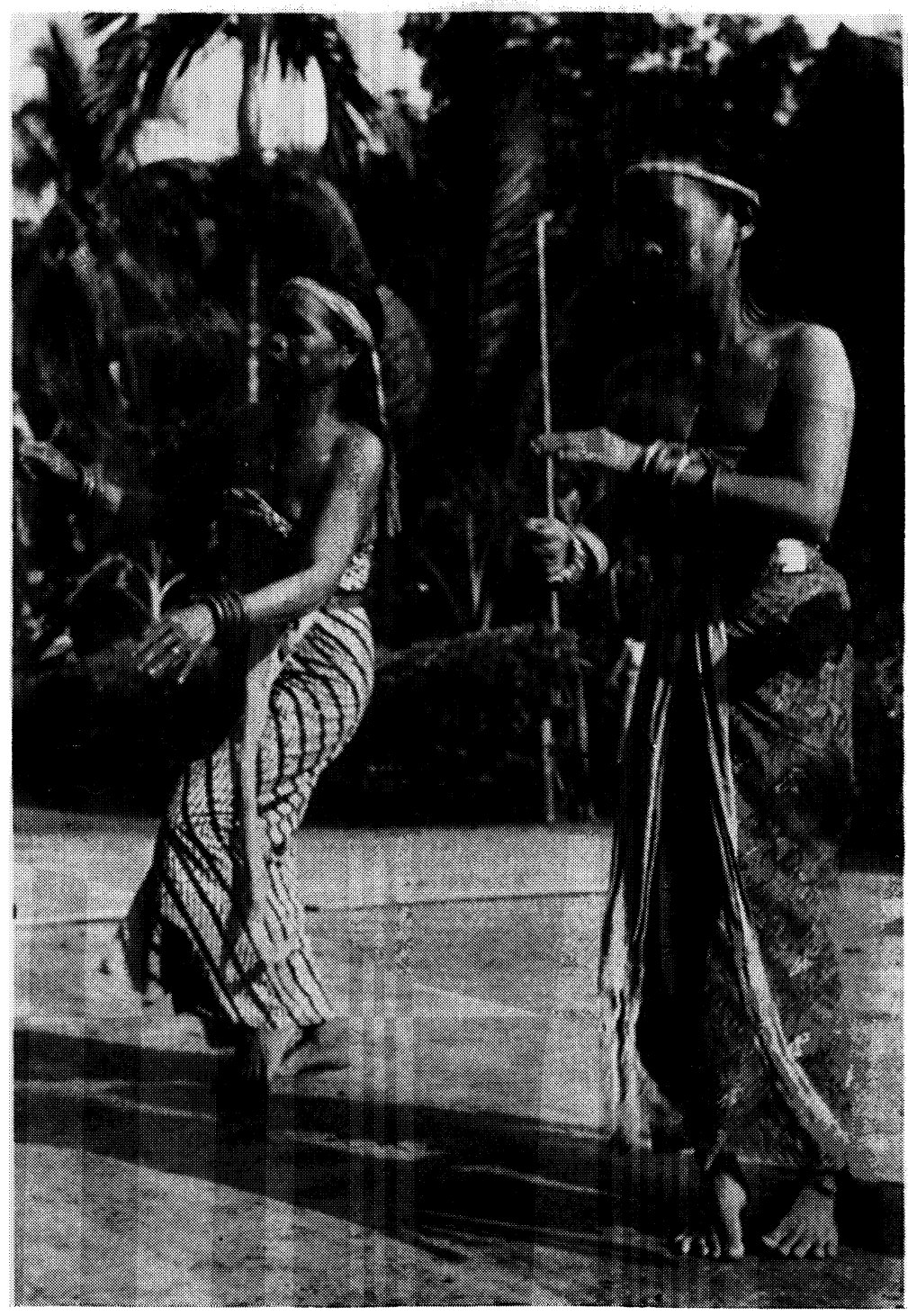

Dadas shamans dance energetically

trained specialists and their less adept apprentices. Beginning students of the shaman's art reacted to trance as did the dancer described above in the shiwa ceremony: their movements became frenzied, they jumped up and down, and were hardly able to dance. In trance, the experienced shaman dances with considerably greater grace than she normally exhibits.

For the bracelet dance, the dadas shaman wears on each wrist four hollow bronze bracelets that are filled with lead shot to make a loud, though pleasant rattle. The dancer shakes her arms vigorously, creating a resounding, repetitious rhythmic pattern in addition to that of the accompanying gongs and drum. The rhythm is repeated incessantly, its beat being vital in inducing trance. The dancer bends her knees and executes a rapid, almost hopping step. As she shakes her bracelets, first one arm and then the other, she may raise her arms as high as her head. Hand gestures are not important, but the rhythmic role of the bracelets is crucial. Among Ma'anjan dances, the fast tempo of the dadas is unique, and for this reason she is usually thought the 


\section{4}

most spectacular and crowd-pleasing of all shaman performers.

The male shaman type, known as bawu, is alleged not to be indigenous to the Ma'anjan tribal area; it is known through much of the drainage of south Kalimantan's great Barito River. The term Bawu itself is the name applied to a small ethnic group, closely related to the Lawangan Dajaks, who inhabit the mountainous regions far to the north and east of Padju Epat territory. One conjectures that this particular healing art orginated among the Bawu people, whence it spread throughout the southeastern part of Kalimantan. Significantly, the bawu's dancing is quite different from any other Ma'anjan dance forms. Only the bawu is accompanied by hoop drums, a trait characteristic of male shamans that has wide distribution throughout Asia. The deafening din set up as these drums are struck with rattan sticks is distinctive, as are the shape and

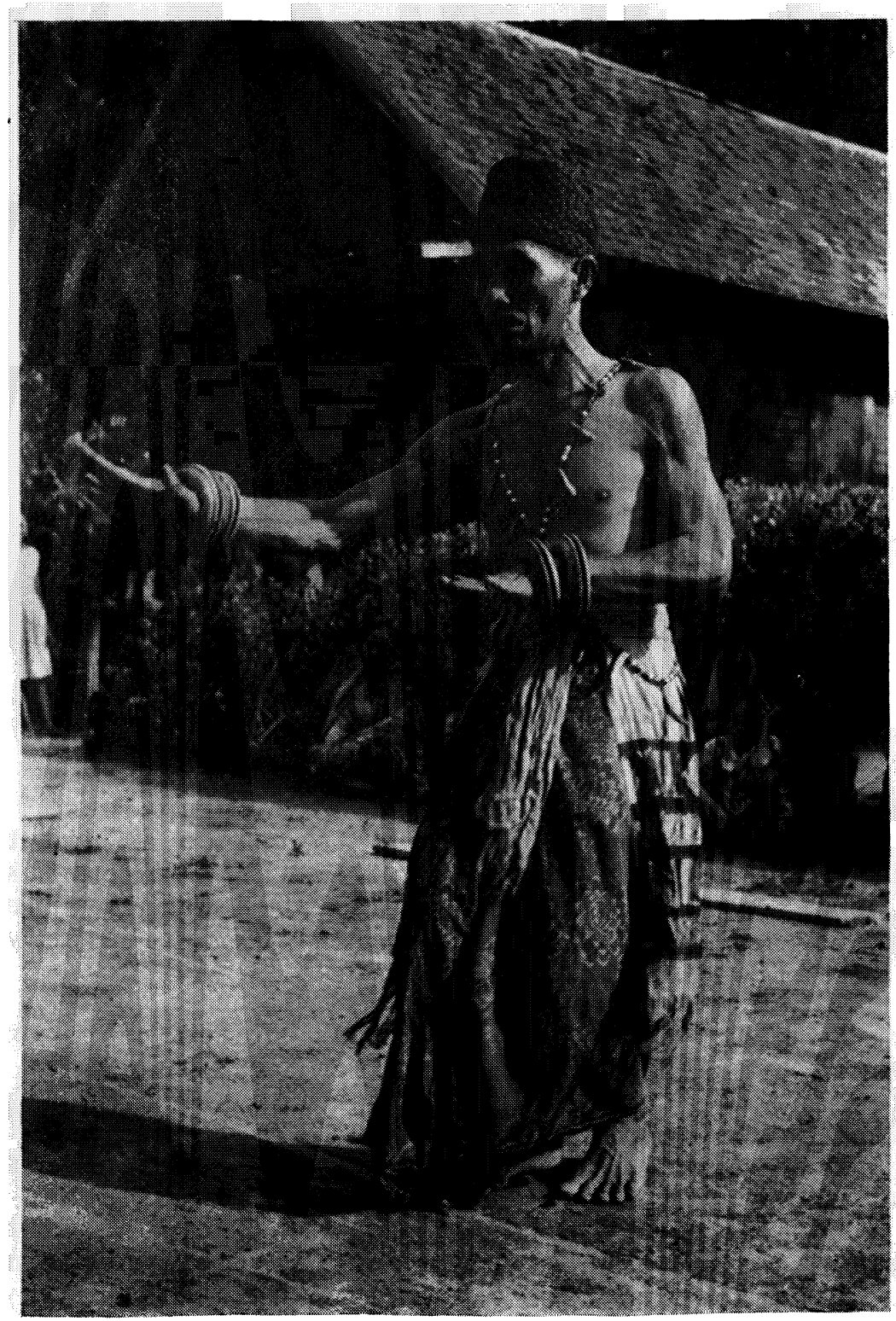

Moment in a bawu shaman's dance 


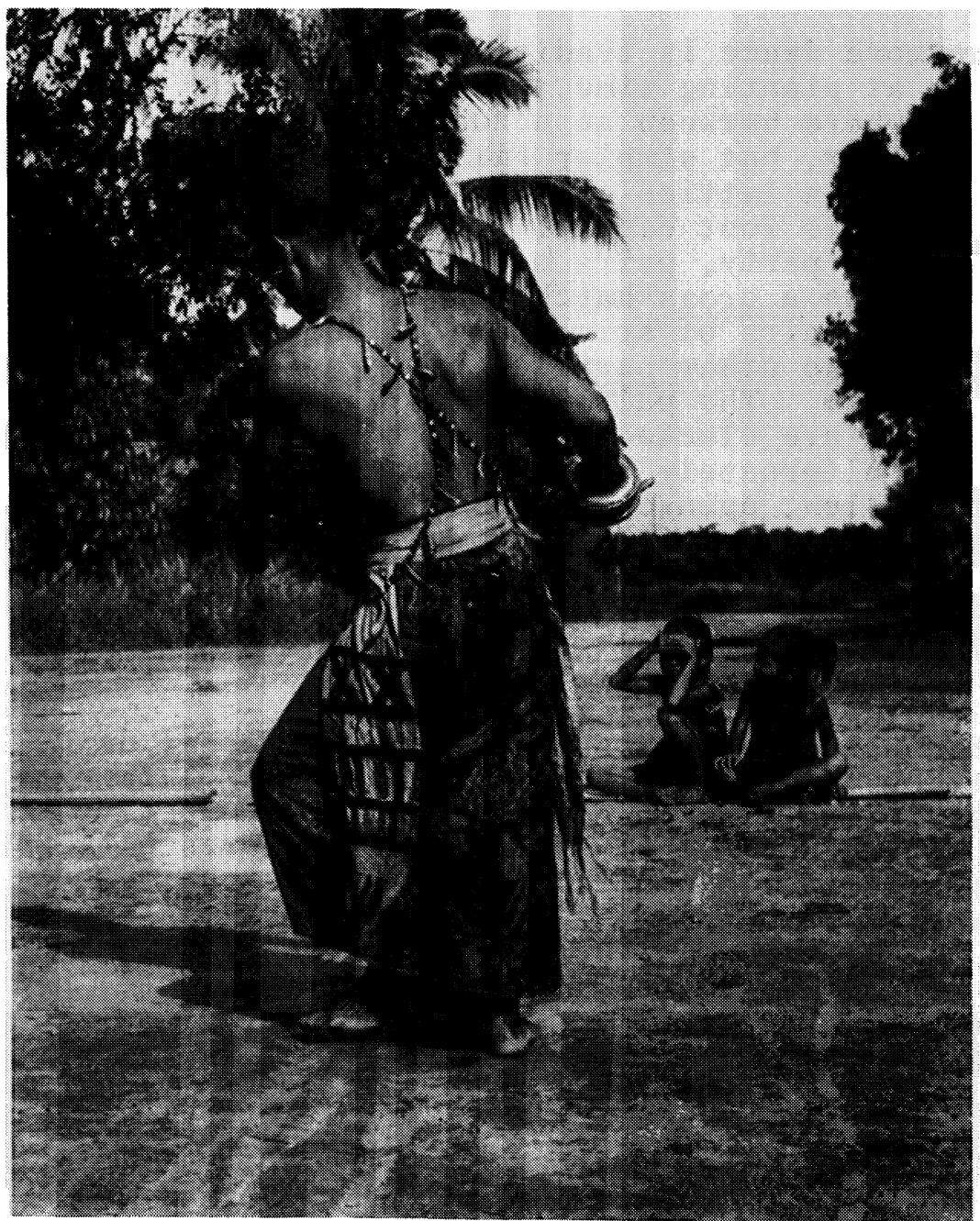

Moment in a bawu shaman's dance

size of the shaman's bronze bracelets.

The bawu's dance begins as he stretches his arms, the right one to the side at chest level, the left one bent at the elbow and parallel with the right. He lowers his body by bending his knees, raises one foot slightly and sets it down again. As he extends his hands, he manipulates the bracelets, gently at first, and they strike together to establish a fixed beat. His hands rotate slowly and gracefully, fingers arched backward, for the bracelets will only clang noisily if given too hard a shake. Throughout, his arms remain parallel; he rotates his body at the hips while his arms move from side to side. His steps become larger as the dance intensifies, he crouches lower to the ground, and his feet stamp down, flatfooted, upon the ground. Suddenly he stops, shakes his bracelets with a loud clatter, and then begins anew.

A slow tempo and undulating arm gestures are as characteristic of the bawu as speed and rapid hops are of the dadas. One of the bawu's curing techniques involves dancing with a lighted taper on his head. Even with the additional stability provided the candle by the shaman's headcloth, it is essential that he not move abruptly. 
One more dance is traditionally performed by the Ma'anjan, exclusively at planting time. The dibble stick dance (tanrik ehek) falls somewhere between an actual dance and an acrobatic exercise. Like a similar, but simpler Filipino dance, the performer must jump in and out of a lattice of opening and closing planting sticks without getting his foot caught. At a rest break during a cooperative rice-planting party, pairs of dibble sticks are aligned on the ground to make a cross-hatched dance floor somewhat like a crossword puzzle. Two pairs of sticks are laid parallel to each other on the bottom, and two other parallel pairs are positioned above at right angles to them. The pairs of dibble sticks, manipulated by a man at each end, are clacked together so that the interstices between the sticks alternately open and close in a catchy, four-beat rhythm, "fast-fast-slow, open-open-close," the closed position of the sticks being held for two beats. The dancer moves in and out of these openings, trying to evade the moving sticks. As he performs increasingly complicated steps, the tempo of the sticks is quickened, and inevitably, his foot is trapped by the sticks as they slap together with a resounding and often painful thwack. ${ }^{6}$

In concluding this section on traditional dance, it might be interesting to consider Ma'anjan dance in relation to what Claire Holt has termed "the Indonesian family of dance." Let us try to relate $\mathrm{Ma}$ anjan dance style to those features with which Mrs. Holt has characterized a general Indonesian dance style. ${ }^{7}$ My own comments are given in parentheses. In brief summary, these features are:

1. The dancer remains close to the ground; he often lowers his body on pliant knees. (Characteristic of all Ma'anjan dances.)

2. Progress in space is accomplished by measured steps rather than leaps or running. (Only in the dibble stick dance are leaps of any type employed.)

3. The dancer does not spin about his own axis. (Some twisting of the body, as with the bawu, is found, but no spinning.)

4. The dancer's hands assume great importance. (In all instances, the dancer's hands are limited by the use of dance accessories.)

5. There is widespread imitation of the motions of birds. (The selendang dance is certainly imitative of birds, bearing considerable resemblance to a Nias dance described by Claire Holt. ${ }^{8}$ )

6. Dance tempi are often slow, with gestures weaving between the musical beats. (Only the dadas shamans

6. For a photograph of the dibble stick dance, see J. Hudson, "Letters," No. 3, p. 134.

7. Claire Holt, Art in Indonesia (Ithaca: Cornell University Press, 1967), pp. 97-99.

8. Claire Holt, "Dances of Nias," Indonesia, No. 11 (April 1971), p. 18 . 
dance to rapid tempi; the Ma'anjan dancer characteristically creates his own ostinato rhythm in opposition to the principal musical beats.)

7. Dancers do not traverse wide spaces. (Shamans dance in and out of the house, when calling their spirits to attend a ceremony; men dancing the special seser bunser style of giring-giring do traverse fairly wide spaces.)

8. Dancing in files or circles is common. (No traditional dancing in files or circles was known among the Ma'anjan. ${ }^{9}$ )

9. A dance scarf or shawl is the most common accessory. (Idiophonic accessories, such as bracelets and rattles, are of equal importance with dance scarves or selendang.)

10. Dance costume, especially a headdress, is inseparable from the dance itself. (Except for shamans, who have special dress, dance costume is not distinctive.)

11. Men dance more often and more vigorously than do women. (In certain forms such as giring-giring, men do dance more frequently and vigorously than women, but the dadas shaman, a woman, is the most energetic Ma'anjan performer. Since proportionally more women than men are shamans, shaman dancing is obviously more often performed by women.)

12. Participants in any given dance are apt to be of a single sex, and physical contact between the sexes never occurs during a dance. (The selendang dance was performed simultaneously by men and women, though in its ceremonial context men began to dance first. Giring-giring may be danced by $a$ boy and girl together. ${ }^{10}$ )

With a few exceptions, then, it would seem that Ma'anjan dance style does follow these generalizations and could perhaps be fitted somewhere on the Indonesian family tree. Two features of Ma'anjan dance style that have no place in this general scheme, however, seem particularly important to emphasize. (1) The persistent use of rhythmic ostinati, and the related sense of competition that may develop between performers or between dancer and musicians. For the audience, this is the spice of the performance, and an individual's success in such contest is a measure of his skill as a dancer.

9. Among many Dajak ethnic groups, circle or file dances are common, however. The adjacent Lawangan people, for example, perform a circle dance, setangkai, as a curing rite.

10. At a kesenian evening following our arrival in the village, my husband and $T$ were asked to perform a European-style waltz. The mere fact that we touched each other was greeted with laughter and some embarrassment. Though we were asked to repeat our performance frequently, no one attempted to emulate it. 
(2) Each performer is free to improvise his own variations on the basic dance form; no movements are dictated by the form of the dance. Two performers rarely synchronize their gestures or steps. Such a dance style is strikingly reminiscent of the individualistic lifestyle of Padju Epat's people.

In today's village life, a new context for dance has been created: an evening of kesenian (1iterally, "arts"), in which dance and singing performances are given, devoid of their ceremonial roles, purely for entertainment. Informants said that this separation of dance from its ceremonial context was quite a recent development. ${ }^{11}$

An evening of kesenian dancing is held on the sandy village street. Spectators gather on each side of the street, sitting on the wooden front steps of adjacent houses or squatting on the ground. Children, dogs, cats, and an occasional pig wander by. The musicians set up their gongs and drum on the ground. To provide resonance for the pounding staffs of the giring-giring dance, several planks are laid on the sand. Often a formal agenda is presented, with stilted speeches, sometimes in Indonesian, serving to introduce the actual dancing.

The occasions and purposes for which a kesenian program of entertainment might be held were varied: to honor a visitor, to make the eve of the periodic market more enjoyable, or merely be organized by local youth to while away their idle hours.

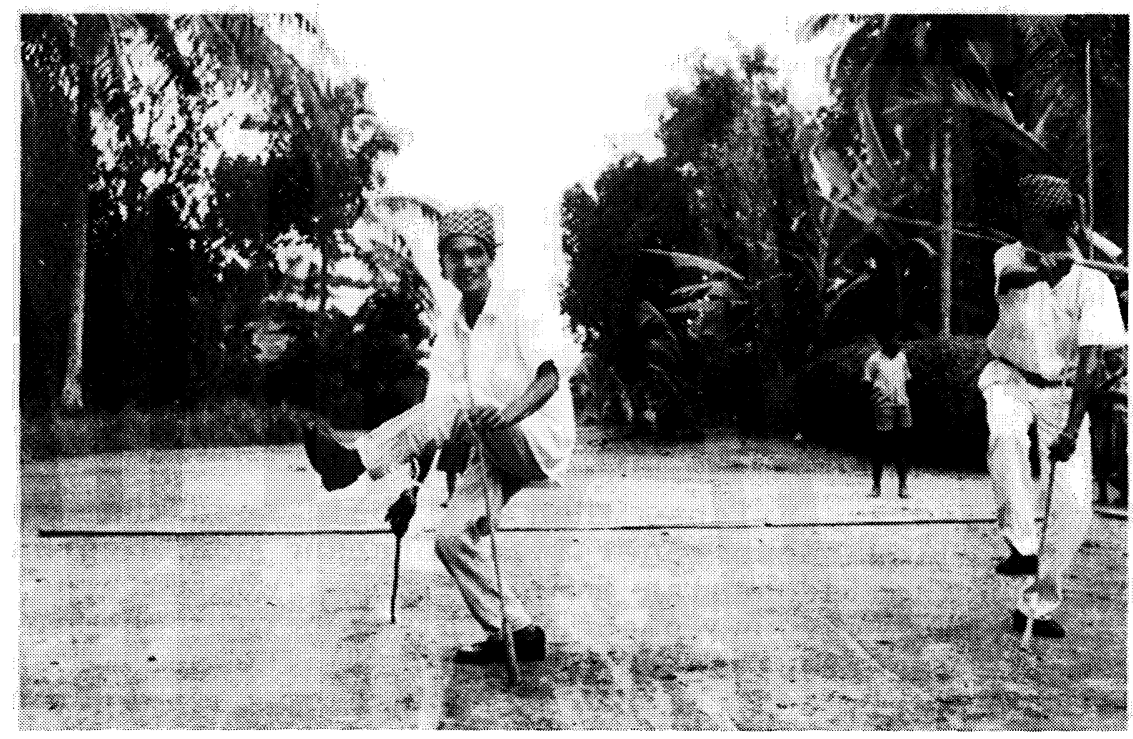

Young men enjoying clowning during giring-giring

11. Some voiced the opinion that such entertainments had begun under the Japanese, when the dibble stick dance, formerly performed only in conjunction with rice-planting sessions, was transformed into purely an art dance. Direct Japanese influence did not have much impact on the isolated region of Padju Epat itself, but possibly the kesenian idea spread there from other areas. It seems possible that the Japanese may have attempted to use indigenous dances to inculcate a sense of "Asian-ness" among the Christian Ma'anjan, in areas where foreign Calvinist missionaries had long forbidden their followers to participate in any such heathen rites as dancing. 
All the traditional dance forms may be employed for such social entertainments, although the principal dance is giring-giring. Once the first two dancers have performed, they present their rattles and staffs to another pair, who must be cajoled onto the dance floor. often as much amusement is afforded the audience by this exchange as by the dancing itse1f. At these evening performances, the younger men delight in absurd gesture during the giring-giring. They balance on one leg, or raise their arms and legs at deliberately awkward angles. The syncopated rhythms of the traditional dance are sacrificed to this absurdity; perhaps the competition here is to see who could be the biggest clown.

The selendang dance is performed at kesenian entertainments by girls in their teens. As is observable in the accompanying photograph, these girls perform a pallid version of the dance. Although appropriately pretty, they move their arms awkwardly; their hands do not operate together in the characteristic, synchronized arm motions of the ceremonial dance. Nor can their shuffling feet execute the measured, lilting steps of an old lady. One element of a new style is apparent here, however. Traditionally the selendang dance is performed by any number of individuals who dance independent1y. Here the girls are trying to move as a group, with hands, arms, and feet following a choreographed pattern.

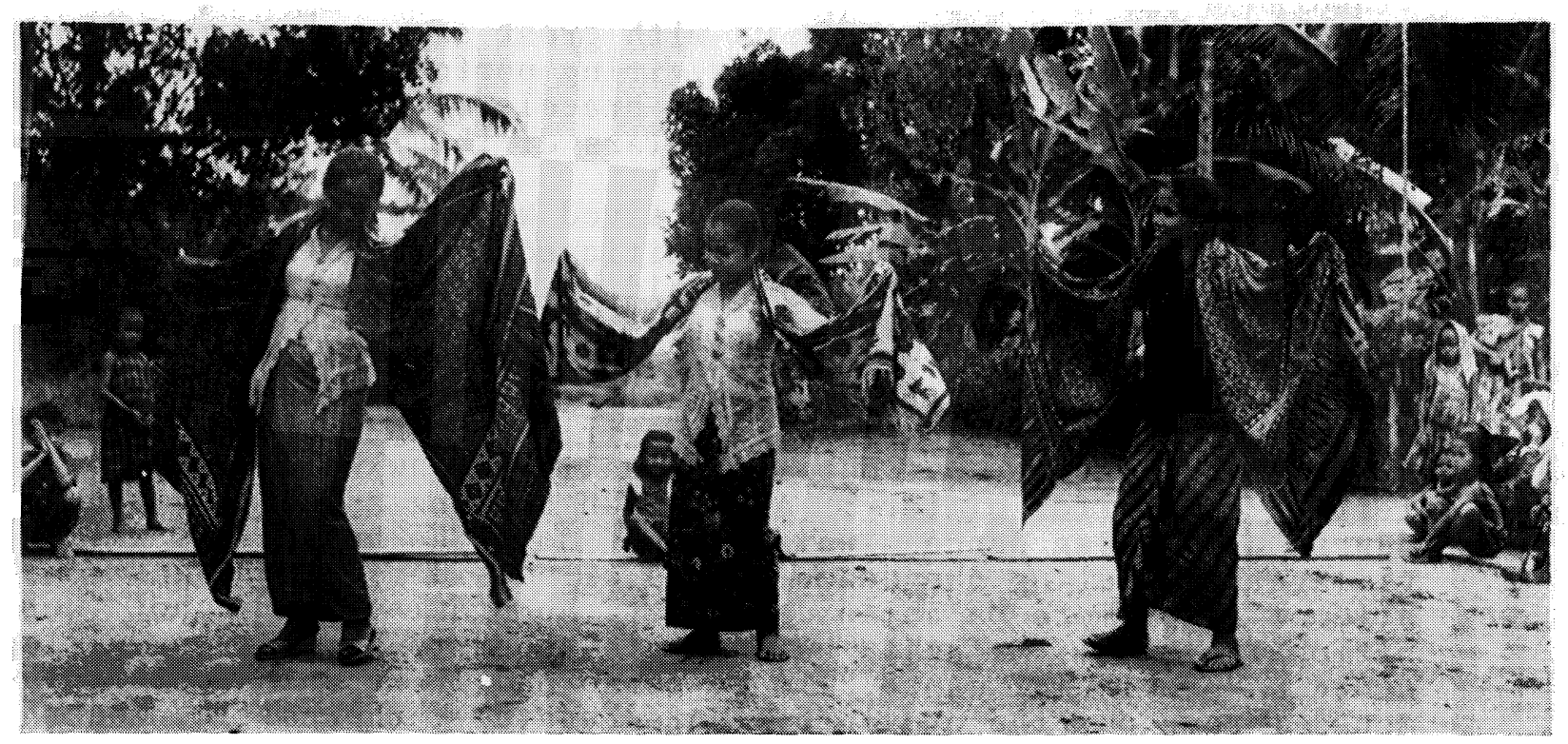

The selendang dance as performed by the young

On occasion, a skilled shaman would be persuaded to perform during an evening's entertainment. In order not to place themselves in ritual danger, they would meticulously prepare offerings for their familiar spirit. Most often, a shaman would be coaxed to perform in honor of a visitor, whose coming he would herald in a number of improvised verses (or pantun). After singing each pantun, the shaman (or shamans) would dance a short, typical fragment. None of the shamans ever approached trance in this context; it was perhaps to avoid trance that only relatively short segments of dance were performed. 
An Indonesian national dance, djoged, had penetrated to the Ma'anjan area in 1964. On some market evenings, a Bandjar Malay orchestra would come by boat to the village, and the strains of modern djoged tunes would be heard late into the night, as young people from all over the surrounding area danced into the small hours of the morning.

The kesenian type entertainment was not only popular in the villages but in larger administrative towns as well. Invariably when visiting dignitaries came to the district headquarters, special dance performances would be mounted for the occasion. Political parties organized dance clubs to perform at such spectacles, each group trying to attract the best performers to give a flashy demonstration, thereby exhibiting to the guests the magnitude of the party's local influence.

Traditional dance styles were subjected to interesting modifications under these conditions. The competitive, individualistic aspects of men's giring-giring disappeared completely, to be replaced by the restricted, cramped movements of the women's style. Choreographed group movement, with dancers performing in geometric patterns and unison gestures, became all the vogue and began to filter back to be incorporated into the village dance style. New combinations of dance forms were invented. One distinguished old man came back from a district-wide meeting of customary law experts to tell us with great admiration of a "Pantja Sila" dance, in which four giring-giring performers joined with another dancer in heavy bawu shaman bracelets, the whole spectacle supposedly symbolic of the Five Pillars of the Indonesian State.

Innovations were generally received with interest and often adopted with enthusiasm. Styles initiated at the district level and imitated by young villagers would be accepted by their elders, although some oldsters might not try the new ways themselves. An innovation that we were directly responsible for provides one very obvious example of the Ma'anjan's receptivity to the winds of change. Our own interpretations of giring-giring were the subject of general hilarity, but our individualistic, awkward styles became fertile ground for mimicry. A Ma'anjan dancing as an American danced a Ma'anjan dance always brought down the house. As well as villagers emulating the dance styles of outsiders, there was some attempt to promote Ma'anjan dances at the provincial, if not the nationa1, level. Ma'anjan bureaucrats hoped to have giring-giring named a "provincial dance," to be performed at kesenian entertainments throughout the province. Unfortunately, the pallid, modern uncompetitive style was to be the prototype for this dance.

In conclusion, it is tempting to speculate upon the future of dance in Padju Epat. That it will change still further under the impact of modernizing influences is evident. New styles have already been incorporated into village dance, and as the dance is increasingly divorced from its traditional ritual context, new forms and combinations will be developed. The ceremonial functions of dance will diminish as kesenian entertainments assume a more dominant role. Ma'anjan dance seems to be responding creatively to the influences of modernization, and if this is so, its vital forces are destined to persevere. 